\title{
An Approach towards Investigating Factors Affecting Intention to Book a Hotel Room through Social Media
}

\author{
Anastasios-Ioannis Theocharidis ${ }^{1}$, Maria Argyropoulou ${ }^{2}$, George Karavasilis ${ }^{1}$, \\ Vasiliki Vrana ${ }^{1}\left[\right.$ and Evangelos Kehris ${ }^{1, *}$ \\ 1 Department of Business Administration, Business School, International Hellenic University, \\ 62124 Serres, Greece; tasos.theocharides@gmail.com (A.-I.T.); gkaravas@ee.duth.gr (G.K.); \\ vrana@ihu.gr (V.V.) \\ 2 School of Humanities Social Sciences and Economics, International Hellenic University, \\ 57001 Thessaloniki, Greece; argyropouloum@gmail.com \\ * Correspondence: kehris@ihu.gr
}

Received: 14 September 2020; Accepted: 22 October 2020; Published: 29 October 2020

\begin{abstract}
Today, social media have become a major trend, and consumers are engaging more and more in the social media platforms used by hotels. This does not mean that they book a hotel room via social media, as the booking process is a complex one. The paper investigates the factors that affect users' intention to book a hotel room using social media applications. The recent enforcement of General Data Protection Regulation (GDPR) in the European Union and California Consumer Privacy Act (CCPA) in California may have an impact on consumers' behavior. To investigate this further, the study integrates into a model the following constructs: Perceived ease of use, perceived usefulness, trust in online hoteliers, social media use, and permission-based-acceptance. The survey was conducted on Greek users of social media. An online questionnaire was used for data collection. The conceptual model was tested using Structural Equation Modeling (SEM) analysis. The study identified four factors that directly or indirectly influence consumers' intention to book hotel rooms through social media. Usefulness directly affects intention to book online. Permission-based acceptance plays a core role in the model. Both constructs trust in online hoteliers and social media use, and have a direct positive effect on permission-based acceptance, whereas permission-based acceptance has a direct positive influence on intention to book through social media. The validated model stretches the need for hoteliers to obtain permission from consumers in carrying out their marketing activities. It is important for hotel owners, managers, and social media specialists to keep consumers in mind, offer them useful information and services, and have a trustworthy behavior in order to boost bookings through social media.
\end{abstract}

Keywords: perceived ease of use; perceived usefulness; trust to online hoteliers; social media use; permission-based-acceptance; SEM

\section{Introduction}

It is a well-accepted fact that the expansion of social media channels has added new digital marketing tools and altered the way consumers collect and process information when making a purchasing decision. The various platforms are used by all kinds of industries, companies, and individuals to share their views, arguments, and experiences. The tourism industry that relies heavily on peer validation has certainly leveraged the tools and opportunities to provide travelers with a plethora of information at their fingertips [1]. The demanding travelers seek various sources of social sharing such as blogs, online reviews, ratings, and photos as well as videos to decide where to go, what 
to see, and where to stay. Social media plays a very important role in all aspects of tourism, which is becoming an increasingly emerging research topic [2].

Hotels constitute the most important super structural elements of the tourism industry, as in most cases, tourism destinations would have no competitive power without the inclusion of accommodation [3]. Building upon this argument, it can be inferred that the increased importance of social media in tourism will have a significant impact on the way hotel guests can share their experiences generating new content that is easily accessible and influential to their peers [4]. Today's travelers are very demanding and look for assistive experiences that are useful, personal, and frictionless; and they also feel that hotel brands should tailor their information based on personal preferences or past behaviors [5]. Social media facilitates real-time exchange of information and interaction between users. The growth of social blogs has become increasingly influential, as they aid hotel customers to easily transmit word-of-mouth information (eWOM) [6]. When the overall statistics about a hotel are negative, people will tend to develop a negative attitude towards the hotel. This will lead to a decrease in their booking intentions [7]. In the same stream of research, Casado-Díaz et al. [8] argue that consumers have significantly lower attitudes toward one hotel after reading negative comments about it in TripAdvisor.

Obviously, this trend has triggered new social marketing strategies adopted by hoteliers who need to be constantly alert for enriching their pages so that their digital customers can have a high-quality social media experience [9]. An understanding of potential customers' intentions is vital for marketers who are eager to utilize social media applications as a part of their strategy. This phenomenon has been explored by several researchers (e.g., $[10,11])$, and it continues to attract researchers' attention due to the tremendous growth of m-commerce [12].

Consumers are now grossly engaged in hotels' social media platforms. In 2018, the General Data Protection Regulation (GDPR) was enforced in the European Union [13]; hotel firms have to develop information governance frameworks and ask for users' permission in carrying out their marketing activities. Due to the GDPR regulation and the intensifying concerns of consumers towards promotional marketing activities, the factor of permission should be taken into consideration.

Traditionally, the hotel industry depends on Global Distribution Systems, Central Reservation Systems, and intermediaries for room sales [14]. However, the industry has experienced tremendous changes brought on by the growth of the World Wide Web and the evolution of electronic channels [15]. Hoteliers invested in both direct and third-party online booking sites, like TripAdvisor, Hotels.com, and Booking.com, to boost their online bookings online [16]. Direct online booking is more efficient and cheaper [17]. On the one hand, third-party online booking sites are easy to access portals of information [18] with effective filtering options and useful management functions [19], sophisticated and transformed into a variety of mobile platforms such as on smart phones or tablets [20]. Potential customers can find hotels at the minimum search cost and maximum utility gained from hotels [21]. Third-party online booking sites help smaller hotels to increase their visibility, occupancy rates, and revenues bypassing their weak brand, small size, and limited competencies in web marketing [22]. Then again, hotel websites enable people to reserve rooms in real time directly from the hotel. Hotels can increase their profits by doing away with the fee charged by third party online booking sites, and even pass on this margin to customers, thus increasing customer loyalty as price is one of the more important factors determining consumer decisions when booking hotel rooms [18]. Marriott with the Best Rate Guarantee assures that the customer always gets the best rate available when booking directly with Marriott. In addition to this, hotels keep the best rooms for themselves to sell directly, and they may be more flexible in case of changes or cancellations because they're not bound by some third-party deal. Thus, hotels are facing a challenge balancing between preserving hotels' profit margins and pursuing sales growth through higher and better visibility offered through third party online booking sites [22].

Nowadays, the use of social media is not restricted only to information search, but is fast becoming an integral part of the overall travel process [23]. Services that were traditionally delivered through 
personal contact can now often be delivered online through social media [24]. Hotels' social media technology gives potential customers' the power to control their travel shopping activities and thus they can make room reservations using them [25]. In the past years, there have been a variety of studies trying to investigate the factors affecting costumers' intentions to book hotels online, using well-established models and theories in the context of computer technologies. A significant number of studies have also discussed the role of permission in mobile advertising [26-28]. However, there are few studies on the factors affecting social media users' intentions to book a hotel using social media platforms [29]. Moreover, the effect of permission-based acceptance for marketing activities on the booking intentions of consumers through social media remains, for the moment, unclear. The paper aims at filling this gap, and it integrates constructs from the Technology Acceptance Model (TAM) with the constructs, trust in online hoteliers, social media use and permission-based acceptance. The conceptual model is tested using Structural Equation Modeling (SEM) analysis.

\section{Literature Review and Research Hypotheses}

\subsection{Perceived Usefulness and Perceived Ease of Use}

The Technology Acceptance Model (TAM) explains the determinants of conscious behaviors toward computer use [30]. TAM intends "to explain the determinants of computer acceptance that is general, capable of explaining users' behavior across a broad range of end-user computing technologies and user populations" [30]. TAM has been widely accepted as a powerful, robust, and parsimonious model capable of explaining how users come to accept and use technology in a variety of contexts [31]. The major advantage of TAM is that it can be extended by using domain-specific constructs when new technologies are introduced [32], and after an extended literature review, it was claimed that TAM is also applicable in a social media context.

According to TAM, perceived usefulness and perceived ease of use of a system mostly influence a person's attitudes and further intention to use the system. Perceived usefulness of a system is defined as "the degree to which a person believes that using a particular system would enhance his or her job performance" [33]. The higher the usefulness of a system, the more acceptance the system would get. Perceived ease of use is defined as "the degree to which a person believes that using a particular system would be free of physical and mental effort" [33]. The easier the use, the more the system would be accepted. Furthermore, perceived usefulness is influenced by perceived ease of use, as the easier it is to use a system, the more it will be perceived as being useful [18].

Venkatesh and Davis [34] proposed the final version of TAM, eliminating the need of the attitude construct, as perceived usefulness and perceived ease of use were found to have a direct influence on intention. Later on, Venkatesh and Davis [35] in an extension of TAM and TAM 2, excluded attitude, as it partially mediates the effect of perceived usefulness and perceived ease of use on intention. Attitude was also not included in TAM 3, proposed in the context of e-commerce and presented as a complete nomological network of the determinants of users' Information Technology System adoption [36]. Exclusion of attitude was further supported in many studies, such as those of Venkatesh et al. [37], Roberts, Ghazizadeh, and Lee [38], Lai and Zainal. [39], Karavasilis et al. [32], and Wu et al. [40]. Thus, attitude was not included in this model.

Previous studies have investigated the impact of perceived usefulness and perceived ease of use on intention-to-use or adoption of social media. Using Cyworld user behavior, Shin [41] confirmed the TAM model and revealed that perceived usefulness and perceived ease of use are factors applicable to the adoption of social media applications. Singh and Srivastava [23] explored the applicability of technology of TAM to explain the widespread acceptance and usage of social media for travel purposes during the travel cycle. Perceived usefulness and perceived ease of use were used as determinants of social media usage. Perceived trust and social capital (SC) were also used as important constructs to explain the travelers' use of social media. Lee and Cho [42] examined the factors that influence the use of social media in a mobile broadband environment. Perceived usefulness is found to form 
attitudes towards Facebook use, while perceived ease of use is an influential factor in the formation of attitudes towards Twitter use. Sledgianowski and Kulviwat [43], who introduced the Social Network Site Adoption model, also proved that usefulness and ease of use have a significant direct effect on the intention to use, while El-Haddadeh et al. [44], in their model of adoption of social networking services, identified the important factors influencing adoption to be ease of use and perceived usefulness, along with trust, loyalty, and advertisement. Mahan [45], studying consumers' preferences for social media, found that "usefulness had significant effects on attitudes toward the use of social media".

Purchase intention can be defined as the likelihood that a customer will buy a particular product/service [46]. In the context of the hotel industry, online booking purchase intention reflects consumers' desire to book a room through the websites of hotels [47]. The present study considers the likelihood that a customer will book a hotel room using a social media platform. Thus, the proposed model includes perceived ease of use and perceived usefulness, and the following hypotheses are formed:

Hypothesis 1. (H1). Perceived ease of use has a positive effect on consumers' intention to book a hotel room through social media.

Hypothesis 2. (H2). Perceived usefulness has a positive effect on consumers' intention to book a hotel room through social media.

\subsection{Trust in Online Hoteliers and Permission-Based Acceptance}

Trust is a cornerstone in business to build relationships with consumers [48]. Trust exists in uncertain and risky environments like e-commerce [49], where online services and products typically are not immediately verifiable [50]. E-commerce transactions are characterized by uncertainty, anonymity, lack of control, and potential opportunism [51], and criminal acts can be performed with high speed [52]. Trust is an effective reduction mechanism. Even though it does not really enable buyers and sellers to control the behavior of each other, it makes it possible to create a comprehensible organization of their activities, ensuring the success of e-commerce [53].

Trust is seen as a fuzzy uncertainty concept [54] and in the e-commerce research domain many definitions exist; some are contradictory and confusing, focusing on willingness to believe or not on a web vendor's attributes such as honesty, fairness, benevolence, good-will, morality, credibility, strength, ability, and predictability [55,56]. One of the most accepted definitions of trust [57] is that of Mayer et al. [58]: Trust is "the willingness of a party to be vulnerable to the actions of another party, based on the expectation that the other will perform a particular action important to the trustor, irrespective of the ability to monitor or control that other party." Walterbusch et al. [59], who studied the term trust, collected definitions, studied their similarities and differences within the Information Systems IS discipline, and identified word clusters for the term; they gave the definition of Whitener et al. [60]: "First, trust in another party reflects an expectation or belief that the other party will act benevolently. Second, one cannot control or force the other party to fulfill this expectation-that is, trust involves a willingness to be vulnerable and risk that the other party may not fulfill that expectation. Third, trust involves some level of dependency on the other party so that the outcomes of one individual are influenced by the actions of another". However, it is not the best fit in most situations.

Trust is also an essential element in social media. In this vein, Kim and Ahmad [61] defined trust as: "A subject's degree of belief in a content provider's task competence, based on the expectation that the content provider generally and consistently delivers satisfactory and high-quality content". In social media, trust represents "a willingness to depend on the other party" with high expectation of satisfying outcomes; and it encourages trustworthy behavior and prevents dishonest behavior of participants. As the definition of trust depends on the researchers' point of view and application domain [59], in this study, trust in online hoteliers represents customers' willingness to depend on hoteliers. 
Permission is the commencement of two-way communications between customers and social media marketers and is a "dynamic boundary produced by the combination of one's personal preferences" [60]. Jayawardhena et al. [15], referring to mobile marketing, claimed that these preferences include personalization of messages in terms of information content location and time. Permission-based marketing refers to consumers opting to receive marketing offers and announcements from a brand [62,63] and requires their overt consent [64]. This pull strategy, initially connected to the concept of opt-in emails, has evolved and is now utilized on a range of different social media platforms [65]. Permission-based marketing ensures that customers pay more attention to the marketing content since they have given their voluntary permission to be a subject of marketing; and it inspires consumers to actively engage in a long-term campaign [63]. Krafft et al. [66] stated that companies with a substantial number of consenting customers have a competitive advantage over others; while those not allowed to actively target customers have reduced opportunities to take orders.

Gao et al. [67], in examining the factors that influence consumers' acceptance of mobile marketing, defined mobile marketing acceptance as "consumers' willingness to provide explicit permission to receive marketing or promotional offers on one's mobile phone, willingness to receive offers from companies selling products, and willingness to receive solicitations from companies". They found that permission-based acceptance has a moderating effect on behavior. Social media applications provide companies with a variety of ways to interact with consumers, and obtain their permission to archive email addresses and personal information so as to receive announcements and marketing offers from them [68].

For effective permission-based marketing, especially in social media, companies need to understand what makes customers willing to give their permission. Trust is an important factor in customers' ability to give permissions. Customers refusing to provide personal information base their decision on a lack of trust and lack of control over how companies use them [69]. Associations have been recorded between trust and consumers' decision to provide personal information to marketers [69-71]. Social media applications enable companies not only to interact, collaborate, and engage with active and potential customers, but also to harness intelligent crowdsourcing for marketing purposes. In order for consumers to have the feeling of being in control and safe, companies have to hold social media accountable for their actions regarding consumers' data, just like the GDPR in the European Union and California Consumer Privacy Act (CCPA) in California [72]. Schweigert and Geyer-Schulz [73] found that GDPR has a significant impact on permission-based marketing activities like email campaigns and social media marketing on Facebook. Permission-based marketing shows that advertising is only successful if the user really wants it and if there is trust between marketers and their clients. Permission-based marketing as a part of the regulation also the user to feel the that company he is dealing with is safe and honest [73].

Given the importance of permission-based acceptance in social media, the model used in this study is a permission-based acceptance model, and as trust is an important factor of customers' ability to give permissions, the following hypotheses were formed:

Hypothesis 3. (H3). Permission-based acceptance has a positive effect on intention to book through social media.

Hypothesis 4. (H4). Trust in online hoteliers has a positive effect on permission-based acceptance.

\subsection{Social Media Usage}

The July 2020 Global Statshot report stated that nearly two-thirds (65\%) of the world's total 'eligible' population uses social media and the adoption is still growing rapidly. Over the past 12 months, worldwide social media users have surged by more than 10\% [74]. A typical social media user is now a member of almost nine different platforms, spending a considerable amount of time [75]. According to a report by Hootsuit 2020 [75], the average date time spend on social media is $2 \mathrm{~h}$ and $22 \mathrm{~min}$, while 
it was $142 \mathrm{~min}$ a day in 2018 and $131 \mathrm{~min}$ in 2017 [76]. As consumers spend more and more of their online time on social media, companies increase their social media marketing budget size [77]. From an organizational standpoint, it is crucial to understand if purchasing intention is positively connected with increased social media usage, then an increase in companies' marketing spending will result in a potential return on investment [78]. Chadwick [79] proposed that consumers that are engaged in social media are significantly more likely to buy and recommend their products more, and Abzari, et al. [80] highlighted that as social media influences consumers' purchasing decisions, companies should encourage consumers to speak to each other about their products and services. The decision-making funnel is growing flatter day by day, and social media applications have the propensity to influence the entire consumer-decision making process, from the beginning to the end [72]. Blomfield-Neira and Barber [81] operationalized the construct of social media usage as the creation of a profile online that others can see, on an SNS like Facebook, Bebo, or MySpace. Hu and Zhang [82] conceptualized and validated the construct of social media usage. This construct "involves an integrative collection of Web2.0 technologies that maintains a variety of online services and applications for people to create and exchange user-generated content" [83]. Social media usage and customers' involvement is a key factor in marketing $[84,85]$, and it was found to be positively related to online wine purchasing behavior [86] and purchasing intention toward luxury fashion [87]. Hussain and Illiasu [83] also claimed that there is a strong relationship between users' online purchasing intention and usage of social media.

Thus, the following hypotheses are formed:

Hypothesis 5. (H5). Social media usage has a positive effect on intention to book through social media.

Hypothesis 6. (H6). Social media usage has a positive effect on permission-based acceptance.

\section{Methodology}

\subsection{Measurement Instrument}

Figure 1 presents the research model and the hypotheses formulated in the study. From the literature discussed above, it is proposed that consumers' intention to book hotels through social media application is based on specific factors: Perceived ease of use, perceived usefulness, social media use, trust in online hoteliers and permission-based acceptance.

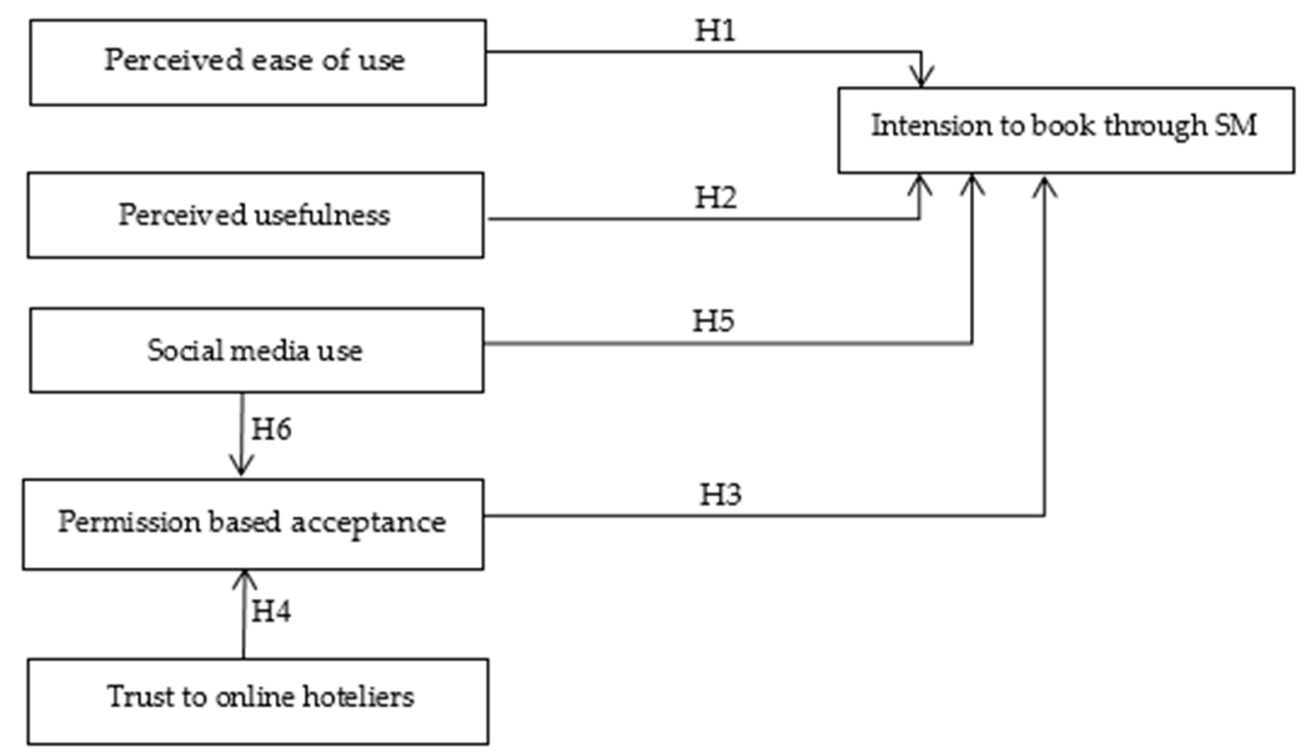

Figure 1. Research model. 
In order to validate the hypothesized model, an online survey with internet and social media users was conducted. The population in the study was users who either used or may use hotel services provided through a social media platform in the future. The questionnaire was hosted on a website and a link to it was posted on Facebook and popular students' blogs. Users selected themselves voluntarily to participate in the study. They were provided with the survey link, and users who were willing to participate in the survey clicked the link and responded to the questionnaire. Thus, the study involved a convenience sample. The questionnaire was written and administered in Greek. The users' responses were recorded in a database. Data collection lasted three months, from 5 February 2018 to 4 June 2018. In total, 640 users completed the questionnaire, and usable questionnaires were received. The questionnaire used in this study was created by adopting constructs and items from previous studies in order to increase the reliability and validity of the study. All items of the questionnaire required five-point Likert scale responses ranging from 1 (strongly disagree) to 5 (strongly agree). The questionnaire consists of six parts: (1) Perceived ease of use, (2) perceived usefulness, (3) social media use, (4) trust in online hoteliers (5) permission-based acceptance, and (6) intention to book through social media. Respondents were also asked a series of demographic, internet experience, and social media experience questions. A pilot study was conducted by administering the questionnaire to 12 social media users $[88,89]$ testing feasibility and the adequacy of the research questionnaire. SPSS Statistics 26 and the lavaan R package for the weighted least squares mean and variance adjusted (WLSMV) estimator were used for the analysis.

\subsection{Sample Description}

The first section of the questionnaire refers to the personal data of the respondents, specifically their gender, age, professional status, level of education, and income. In a total of 640 respondents, $57.5 \%$ were men and $42.5 \%$ were women. Regarding the age of the respondents, those between 21 to 30 were $27.5 \%$, between 31 to 40 were $20.6 \%$, and between 41 to 50 were $29.4 \%$. Respondents less than 20 and those aged 51-60 and 60 and above were $0.6 \%, 19.7 \%$, and 2.2\%, respectively. An open questionnaire was used to record their professional status. $44.1 \%$ of the respondents are public sector employees, $22.5 \%$ are private-sector employees, and $13.4 \%$ are university students. The respondents are well educated, as $38.4 \%$ have a university Bachelor's degree, $36.3 \%$ have a Master's degree, and $12.8 \%$ have a PhD. degree.

The sample consists of people who,

- have Internet experience ( $76.9 \%$, over 10 years, and $21.9 \%$, from 3 to 10 years' experiences);

- have social media experience (61.3\%, 3-10 years, and 31.6\%, more than 10 years' experiences);

- use the Internet extensively (39.1\%, more than $20 \mathrm{~h}$ a week; 31.6\%, 11-20 h, and 14.1\%, 6-10 h);

- use social media (24.7\%, more than $20 \mathrm{~h}$ a week; $26.3 \%, 11-20 \mathrm{~h}$, and $22.5 \%, 6-10 \mathrm{~h}$ ).

\section{Findings and Discussion}

\subsection{Model Estimation}

For data with five or less ordered categories, a robust diagonally weighted least square (DWLS) estimator was used ([90], p. 475). The study used the lavaan R package for the weighted least squares mean and variance adjusted (WLSMV) estimator [91,92].

\subsection{The Measurement Model}

Structural Equation Modelling (SEM) was used to test the framed hypotheses. However, before doing so, the measurement model was examined for the validation of the research constructs. Confirmatory Factor Analysis was used to refine the model of the study. Convergent validity, discriminant validity, and internal consistency of the constructs were employed to test the measurement model. Factor loadings, composite reliability, and average variance extracted for the reliability and 
convergent validity of the constructs were also used [93]. The constructs, items, and factor loadings used in the study are presented in Table 1.

Table 1. Items used and Confirmatory Factor Analysis (CFA)loadings.

\begin{tabular}{|c|c|}
\hline Items Used & Factor Loadings \\
\hline \multicolumn{2}{|l|}{ Social Media Use (SME) (adapted from Akar and Topçu [94]) } \\
\hline I use social networking sites such as Facebook regularly & 0.706 \\
\hline I like using social media applications such as YouTube, Facebook, and blogs & 0.728 \\
\hline \multicolumn{2}{|l|}{ Trust to online hoteliers (TRU) (adapted from O'Cass and Carlson [95]) } \\
\hline I feel safe in my transactions with hotels' social media applications & 0.852 \\
\hline Profiles of hotels' social media are trustworthy & 0.783 \\
\hline $\begin{array}{l}\text { I feel that any information communicated by the hotels' social media applications } \\
\text { is secure }\end{array}$ & 0.674 \\
\hline \multicolumn{2}{|l|}{ Ease of use (EOU) (adapted from Karavasilis et al. [32]) } \\
\hline Learning to interact with social media used by hotels would be easy for me & 0.772 \\
\hline $\begin{array}{l}\text { I believe interacting with social media used by hotels would be a clear and } \\
\text { understandable process }\end{array}$ & 0.824 \\
\hline I find most social media used by hotels to be flexible to interact with & 0.825 \\
\hline It would be easy for me to become skillful at using social media used by hotels & 0.708 \\
\hline \multicolumn{2}{|l|}{ Usefulness (USEF) (adapted from Karavasilis et al. [32]) } \\
\hline Using social media used by hotels enables me to do business with them anytime & 0.770 \\
\hline Using social media used by hotels enables me to accomplish tasks more quickly & 0.820 \\
\hline The results of using social media used by hotels are apparent to me & 0.824 \\
\hline Using social media used by hotels can cut booking time & 0.732 \\
\hline Using social media used by hotels can make the booking procedure easier for me & 0.834 \\
\hline \multicolumn{2}{|l|}{$\begin{array}{l}\text { Permission Based Acceptance (adapted from Gao et al. [67]) } \\
\text { From a hotel that asks my permission.... }\end{array}$} \\
\hline I would be willing to receive offers on my social media accounts from hotels & 0.884 \\
\hline $\begin{array}{l}\text { I would be willing to receive offers real time on my social media accounts from } \\
\text { a nearby hotel }\end{array}$ & 0.707 \\
\hline $\begin{array}{l}\text { Overall, I would be willing to receive offers on my social media accounts from } \\
\text { hotels to whom I gave my permission }\end{array}$ & 0.890 \\
\hline \multicolumn{2}{|l|}{ Intention to book through social media (adapted from Gao et al. [67]) } \\
\hline Booking online through social media applications & 0.935 \\
\hline Managing bookings through social media applications & 0.955 \\
\hline
\end{tabular}

Convergent validity was assessed using two methods to measure "the extent to which the items under each construct are actually measuring the same construct" ([32], p. 9). The factor loading of each variable, which should exceed the cut-off point of 0.55 [96], and the average variance extracted (AVE) for each construct, which should be above 0.5 [96,97]. The AVE for a construct, "reflects the ratio of the construct's variance to the total variance among the items of the construct" ([32], p. 9). As it is recorded in Table 1, all the factor loadings are above the cut-off point. Similarly, Table 2 shows that the AVE values of the constructs are above the suggested threshold level (0.5), indicating the reliability of the measurement model in measuring the construct. 
Table 2. Composite reliability (CR) and average variance extracted (AVE) of the constructs.

\begin{tabular}{lcc}
\hline Construct & CR & AVE \\
\hline Perceived ease of use & 0.853 & 0.613 \\
Perceived usefulness & 0.951 & 0.632 \\
Permission-based acceptance & 0.951 & 0.687 \\
Trust in online hoteliers & 0.853 & 0.608 \\
Social media use & 0.775 & 0.512 \\
Intention to book through social media & 0.938 & 0.659 \\
\hline
\end{tabular}

Discriminant validity for this study was also examined to test "the extent to which a given construct differs from other constructs" [32]. The results did not raise any concerns, as all items loaded clearly on their corresponding construct. Square roots of AVEs are larger than correlations among constructs, therefore satisfying discriminant validity. Table 3 shows that all inter-construct correlations are below 0.9, which indicates distinctness of the constructs' content or discriminant validity $[97,98]$.

Finally, the composite reliability (CR) of the constructs are above 0.6 [99], as shown in Table 2. $\mathrm{CR}$ relies on actual loadings to compute the factor scores, and thus provides a better indicator for measuring internal consistency [96] compared to Cronbach's alpha, which assumes equal weights of all the items of a construct and is influenced by the number of items. Composite reliability in all items are above the threshold level 0.7 (Table 4). Overall, the measures in this study are reliable and valid.

The next step taken was the model estimation. The recommended fit indices [96] are depicted in Table 5: Chi-square, goodness of fit index, (GFI), normed fit index (NFI), non-normed fit index (NNFI), comparative fit index (CFI), and root-mean-square error of approximation (RMSEA). Bagozzi and Yi [96] suggested the use of suggested a chi-square per degree of freedom instead of chi-square when the sample sizes exceed 200 respondents [93]. All the fit indices in Table 5 indicate that the structural model has a good fit.

\subsection{The Validated Model}

The study identified four factors that directly or indirectly influence the intention to book through social media. These factors (Figure 2) are perceived usefulness, permission-based acceptance, social media use, and trust in online hoteliers.

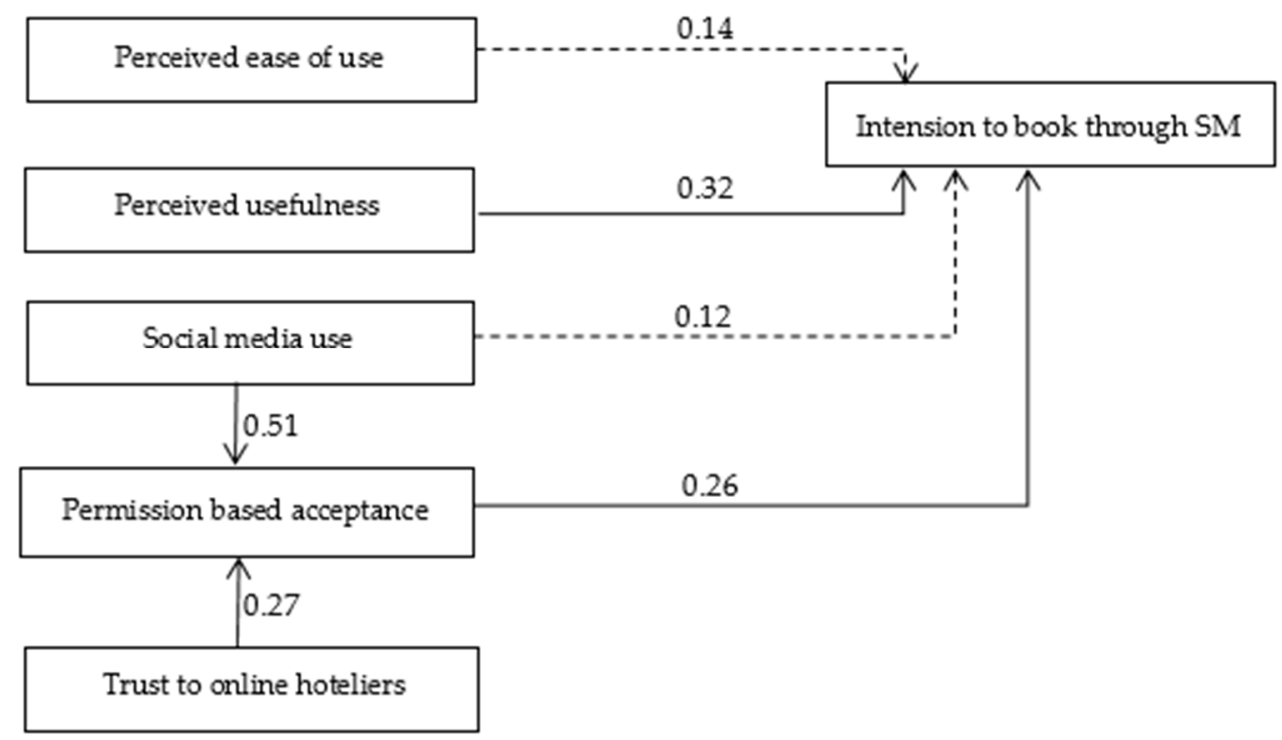

Figure 2. The validated model. 
Table 3. Inter-construct correlations.

\begin{tabular}{|c|c|c|c|c|c|c|}
\hline & $\begin{array}{l}\text { Perceived Ease } \\
\text { of Use }\end{array}$ & $\begin{array}{l}\text { Perceived } \\
\text { Usefulness }\end{array}$ & $\begin{array}{l}\text { Permission-Based } \\
\text { Acceptance }\end{array}$ & $\begin{array}{l}\text { Trust in Online } \\
\text { Hoteliers }\end{array}$ & $\begin{array}{l}\text { Social Media } \\
\text { Use }\end{array}$ & $\begin{array}{l}\text { Intention to } \\
\text { Book through } \\
\text { Social Media }\end{array}$ \\
\hline Perceived ease of use & 1.000 & & & & & \\
\hline Perceived usefulness & 0.644 & 1.000 & & & & \\
\hline Permission-based acceptance & 0.437 & 0.410 & 1.000 & & & \\
\hline Trust in online hoteliers & 0.592 & 0.469 & 0.385 & 1.000 & & \\
\hline Social media use & 0.537 & 0.551 & 0.572 & 0.218 & 1.000 & \\
\hline Intention to book through social media & 0.515 & 0.574 & 0.517 & 0.354 & 0.512 & 1.000 \\
\hline
\end{tabular}


Table 4. Cronbach a.

\begin{tabular}{lc}
\hline Construct & Crombach a \\
\hline Perceived ease of use & 0.863 \\
Perceived usefulness & 0.897 \\
Permission-based acceptance & 0.869 \\
Trust in online hoteliers & 0.826 \\
Social media use & 0.888 \\
Intention to book through social media & 0.943 \\
\hline
\end{tabular}

Table 5. Goodness of fit (GFI). AGFI: Adjusted goodness-of-fit index; NFI: Normed fit index; NNFI: Non-normed fit index; RMSEA: Root-mean-square error of approximation; CFI: Comparative fit index.

\begin{tabular}{lc}
\hline Fit Index Compared to the Recommended Value & $\begin{array}{c}\text { Measurement } \\
\text { Model }\end{array}$ \\
\hline Chi-square/d.f. $\leq 3.0$ & 0.76 \\
GFI $\geq 0.80$ & 0.988 \\
AGFI $\geq 0.80$ & 0.983 \\
NFI $\geq 0.90$ & 0.981 \\
NNFI $\geq 0.90$ & 1.007 \\
RMSEA $\leq 0.08$ & 0.000 \\
CFI $\geq 0.90$ & 1.000 \\
\hline
\end{tabular}

The findings do not support the role of perceived ease of use as a fundamental factor in the intention to book through social media $(\gamma=0.14, p<0.05)$, so H1 is not supported. Previous studies investigating the applicability of TAM within the domain of social media marketing context found contradictory results. Perceived ease of use was found to have a significant and positive effect on the level of behavioral intention in many studies, such as those of Hansen et al. [100]; Sin et al. [101], and Yahia et al. [102]; while in other studies such as those of Kanchanatanee et al. [103]; Mariani et al. [104], and Saprikis et al. [105]. Lee and Lee [106] claimed that the correlation of perceived ease of use with behavioral intention is not always supported as in Lee, Kozar, and Larsen's [107] meta-analysis of 101 studies related to TAM, only 58 studies showed a significant relationship between perceived ease of use and behavioral intention, indicating that perceived ease of use is an unstable measure in predicting behavioral intention.

Perceived ease of use did not have a significant and positive influence on behavioral intention. In the past years, social media have been spreading around the globe and has become an integral and substantial part of people's everyday life. They are user-friendly, easy to use and navigate, and require very little knowledge of the internet or mental effort. As users are more digitally aware, and have certain experiences and habits using social media platforms, ease of use is considered as a "given" by users; therefore, it seems not to be important anymore.

Perceived usefulness directly influences intention to book through social media $(\gamma=0.32, p<0.05)$, so H2 is supported. This finding is consistent with previous studies such as Hajli [48] and Cha [108]. The more consumers perceive social media platforms to be useful, the higher their intention to buy things via them. Hotels' profiles on social media represent usefulness because they have become channels to obtain quality information for hotels and are simple and fast booking channels. Information that may be useful to existing and potential customers could include up-to-date customer reviews, or running contests and events.

Permission-based acceptance has a direct positive influence on the intention to book through social media $(\beta=0.26, p<0.05)$. Thus, $\mathrm{H} 3$ is supported. Permission is the beginning of the communication between a company and a customer, and the starting point of building long-term relationships. The consent of information exchange helps to develop the relationship between a company and a customer. In mobile advertising, it was found that consumers have a more positive attitude after 
agreeing to receive the advertisement, while consumers who did not give permission to companies to send them adverts tend to ignore them [109]. This is also the case in this study. Hotels should treat people with respect on social media; it is the best way to gain their attention.

Trust in online hoteliers has a direct positive influence on permission-based acceptance $(\gamma=0.27$, $p<0.05)$. The more customers trust online hoteliers, the easier it would be for them to give permission to hotels to do their marketing activities. Kautonen et al. [110] claimed that "a continuous presence in the media increases the general trustworthiness of a company". Thus, it is extremely important for companies to be well-known on social media and make their hotel a desirable destination across all channels. By using content marketing and putting the right content in the right place through hotels' social media strategies, hotels would make themselves known.

Interestingly, a hotel's good presence in social media implies the trustworthiness of the hotel, and it helps customers to decide to provide personal information and grant permission. As $\mathrm{H} 3$ is supported, trust in online hoteliers has a statistically significant indirect effect on the intention to book through social media (coefficient $=0.072$ ), as it is shown in Table 6. Trustworthy relations between consumers and online hoteliers can lead to higher intentions to book hotels online using social media. The findings of this study confirm the findings of Agag and El-Masry [111] that consumers' trust is a driver of consumers' intention to book online.

Table 6. Standardized indirect effects.

\begin{tabular}{|c|c|c|c|c|}
\hline & Estimate & Std.Err & z-Value & $P(>|z|)$ \\
\hline $\begin{array}{l}\text { Social media use on } \\
\text { intention to book } \\
\text { through social media }\end{array}$ & 0.134 & 0.071 & 2.549 & 0.011 \\
\hline $\begin{array}{l}\text { Trust in online hoteliers } \\
\text { on intention to book } \\
\text { through social media }\end{array}$ & 0.072 & 0.041 & 2.055 & 0.040 \\
\hline
\end{tabular}

Next, the indirect effects of social media use and trust to online hoteliers on the intention to book through social media and total effect of social media use on the intention to book through social media have been tested and they are statistically significant, as is presented in Table 6.

Social media use has no significant and direct positive effect on the intention to book through social media $(\gamma=0.12, p<0.05)$. It is supposed that the more people use social media, the higher their intention to book through social media (H5), but it is not supported. However, as social media use has a significant and direct positive effect on permission-based acceptance ( $\beta=0.52, p<0.05), \mathrm{H} 6$ is supported. Additionally, social media use has a statistically significant indirect influence on intention to book via social media through permission-based acceptance (coefficient $=0.134, p$-value $=0.011$ ).

Furthermore, the total effect of the social media use on intention to book through social media is also statistically significant $(\mathrm{z}$-value $=2.458, p$-value $=0.014)$, with a standardized coefficient of 0.250 .

The more people use social media, the easier it is for them to give permission to hotels to do their marketing activities, as they feel more "in control" and "safe", which are necessary factors where privacy is concerned [112]. The extended use of social media makes consumers believe that hotels hold social media accountable for their actions regarding users' data. The presence of a hotel on social media makes it easier for consumers to find the hotel and connect with it. Through this connection, hotels are more likely to upsurge customers' retention and loyalty.

\section{Conclusions and Future Research Directions}

This research paper contributes to the understanding of social media use behavior in the tourism industry. The paper proposes and validates a model for investigating the factors affecting consumers' intention to book a hotel online using social media. Previous studies have confirmed the applicability of TAM within the domain of social media context via its modifications and extensions [113]. Consistent with this approach, this research uses perceived ease of use and perceived usefulness as a base, and 
integrates the model with the constructs social media use, trust in online hoteliers, and permission-based acceptance. The model identifies four factors that directly or indirectly influence users' intention to book a hotel online using social media and raises major issues facing the hospitality industry regarding social media strategies that owners, hotel managers, and even social media specialists should take into account to increase customers' intention to book. Some very interesting findings are drawn from the data analysis.

Perceived usefulness affects directly intention to book online. Hoteliers should design informative, effective pages on social media where users can find valuable content and information. According to Cha [108], the more people perceive the shopping services on social media as being useful, the more likely they are to shop using them. Social media with sophisticated targeting capabilities allow hotels to identify ideal customers for them and to serve them with relevant advertising content and personalized services. Users, in turn, perceive personalized services as more useful and are more likely to make a purchase [114].

Therefore, it is important to design marketing campaigns in alignment with customers' requirements and needs. Collecting information is the best way to design a purposeful campaign. The introduction of new regulation, the General Data Protection Regulation (GDPR) 2016/679 in 2018 in the European Union, as well as the California Consumer Privacy Act (CCPA) in 2020 in California, USA may have impacts on consumers' behavior.

The paper introduces a permission-based acceptance construct, previously used in mobile marketing, and investigates its impact on consumers' booking intention through social media. Trust in online hoteliers and social media use may have an impact on permission-based acceptance, and thus they were integrated into the model. Permission-based acceptance plays a core role in the model. Both constructs trust in online hoteliers and social media use, and have a direct positive effect on permission-based acceptance whereas permission-based acceptance has a direct positive influence on intention to book through social media. Thus, trust in online hoteliers and social media use have an indirect positive effect on the intention to book through social media. The more users trust online hoteliers and the more they use social media, the easier it is for them to give their permission to the hotels to market their products. Duncan and Moriarty [115] claimed that in customer-focused marketing activities, communication is the basis to build a long-term relationship. We reiterate Duncan and Moriarty's [115] opinion that it is extremely important for hotels to be well-known on social media and have a trustworthy behavior. User-generated content, photos, likes, positive comments, and recommendations may positively influence users.

In terms of practical implications, the findings offer insight for hotel owners or managers who are using social media and digital marketing tools to improve their performance. Hoteliers can enhance their understanding of the factors that affect consumers' intention to book a hotel using social media applications. Moreover, the paper integrates factors related to regulatory policies that may lead to meaningful differences in how privacy concerns can be satisfied and trust maintained or even enhanced. A holistic view of the role of social media is important to create innovative profiles and opportunities that can serve the company and the customer needs.

In recent years, there has been an explosion of social media attracting a wide range of users and creating an endless marketplace. As a vast number of consumers are using social media every day, this is a great opportunity for hotels to reach their online audience. It is vital for hotel marketers to understand the factors that affect consumers' behavior, recognize the various drivers of, and obstacles to, intention to book online using social media and invest wisely on social media marketing strategies. In the fast-changing knowledge economy, it is of vital importance that businesses use social media without breaching the user's privacy. Policy makers can also use the findings to boost the hospitality industry that is one of the fastest growing industries in Greece and contributes substantially to the economic growth of the country, linking the economic, social, and environmental components of sustainability [116]. In the hospitality industry, sustainability turned from a nice-to-have into a business imperative as more and more people not only make sustainable travel choices, but are 
willing to pay more for them [117]. Recent research attests to the use of social media platforms as new arenas for the co-construction of values such as sustainability [118]. As sustainability has turned into a competitive advantage for all companies [119], hotels can use digital marketing to promote financially justifiable practices towards the general wellbeing of all stakeholders. Building upon these arguments, the model can be used by policy contributors as an evidence-based tool to make the hospitality industry an economically sustainable sector.

The tourism industry is highly vulnerable to risks of environmental and socio-economic nature, but manages to bounce back [120]. However, the recent COVID-19 pandemic has caused far too many disruptions of global scale, leading to a worldwide recession dramatically affecting the tourism sector, which now suffers an unprecedented decline [121].

Academic and practitioners should respond by exploring ways that enhance industry practices for a more sustainable tourism economy. For the purposes of this study, the emphasis is placed on how hoteliers should address changes in consumer demand and restore travelers' confidence [122]. One way to do so would be reassurance of hotel cleanliness and hygiene. Travelers are seeking such information before deciding on accommodation, and are now more likely to pay attention to cleanliness measures when making travel decisions. Grounded on the ideas proposed by the authors and based on the findings of this research, it is recommended that hygiene measures and precautions should be clearly communicated and promoted as a selling point using all possible digital marketing tools. The results of this research concur with the findings from Jiang and Wen [122], who advocated healthcare-related features to influence the traveler's decision-making process. Hoteliers can engage with their customers on social media. Given this state of affairs, the hotel industry's sustainability can be solidified by respecting customer fear, addressing traveler wellness, and establishing contingency plans. Future research can focus on how the social media can be used as a tool to protect tourism against similar disruptions with the ultimate goal of sustainable development especially in developing countries.

\section{Limitations of the Study}

The final validated model describes associations among preselected variables suggested by the literature related to recently introduced regulatory policies. Although the results of the study shed light on several issues, the study is not free from limitations. First, the findings should be interpreted with caution and cannot be generalized, as they are country specific, and a convenience sample of social media users in Greece was used. Internet penetration in Greece stands at 79\%, and social media penetration stands at 59\%, increased by 5\% between April 2019 and January 2020 [123], but remains well below the EU average [124]. Future research in different countries should consider other factors such as internet penetration and availability. Next, the study integrates constructs from multiple theories in an approach to understand how hotel customers engage in booking a room through social media, using the particular set of variables. The model indeed describes and measures how the particular variables associate to each other; and it is an adequate model. Future research may look into other theories and factors to predict hotel consumers' behavior when booking a room through social media. The different models describe and measure different sides of the phenomenon, and may be equally correct and important. Further research is needed, as the model may be extended by adding other variables (as perceived risk, price, service quality) that can be used to measure different aspects of the phenomenon. Having said that, future studies can test our findings in other tourism sectors to combine social media and digital tourism marketing in harmony.

Author Contributions: A.-I.T. conceptualized the research work; G.K. validated the research tools; A.-I.T. and G.K. did the formal analysis and the research investigation; M.A., V.V., E.K. did the original write up and draft preparation; M.A. and E.K. did the writing, review, and editing of the work; A.-I.T. and V.V. did the visualization, supervision, and administration of the project; All authors have read and agreed to the published version of the manuscript.

Funding: This research received no external funding.

Conflicts of Interest: The authors declare no conflict of interest. 


\section{References}

1. Sudipta, K.S.; Babu, G. Social media technologies in the tourism industry: An analysis with special reference to their role in sustainable tourism development. Int. J. Tour. Sci. 2018, 18, 269-278.

2. Zeng, B.; Gerritsen, R. What do we know about social media in tourism? A review. Tour. Manag. Perspect. 2014, 10, 27-36. [CrossRef]

3. Attila, A.T. The Impact of the Hotel Industry on the Competitiveness of Tourism. J. Compet. 2016, 8, 85-104.

4. Jung, T.; Dieck, M.; Chung, N. Determinants of hotel social media continued usage. Int. J. Contemp. Hosp. Manag. 2018, 30, 1152-1171. [CrossRef]

5. Torres, R. How to Win Travelers in the Age of Assistance. 2018. Available online: https://www. thinkwithgoogle.com/consumerinsights/age-of-assistance-travel-marketing/ (accessed on 13 May 2019).

6. Abou-Shouk, M.A.; Hewedi, M.M. Antecedents and consequences of social media adoption in travel and tourism: Evidence from customers and industry. IJEME 2016, 10, 652-659.

7. Sparks, B.A.; Browning, V. The impact of online reviews on hotel booking intentions and perception of trust. Tour. Manag. 2011, 32, 1310-1323. [CrossRef]

8. Casado-Díaz, A.B.; Andreu, L.; Beckmann, S.C.; Miller, C. Negative online reviews and webcare strategies in social media: Effects on hotel attitude and booking intentions. Curr. Issues Tour. 2020, 23, 418-422. [CrossRef]

9. Leung, D.; Law, R.; van Hoof, H.; Buhalis, D. Social media in tourism and hospitality: A literature review. J. Trav. Tour. Mark. 2013, 30, 3-22. [CrossRef]

10. Jung, T.; Ineson, E.; Green, E. Online social networking: Relationship marketing in UK hotel. J. Mark. Manag. 2013, 29, 393-420. [CrossRef]

11. Matikiri, R.; Mpinganjira, M.; Roberts-Lombard, M. Application of the Technology Acceptance Model and the Technology-Organisation-Environment Model to examine social media marketing use in the South African tourism industry. S. Afr. J. Inf. Manag. 2018, 20, e1-e12.

12. Yang, K.C.; Kang, Y. Exploring big data and privacy in strategic communication campaigns: A cross-cultural study of mobile social media users' daily experiences. IJOSC 2015, 9, 87-101. [CrossRef]

13. Hoofnagle, C.J.; van der Sloot, B.; Borgesius, F.Z. The European Union general data protection regulation: What it is and what it means. ICTL 2019, 28, 65-98. [CrossRef]

14. Hu, X.; Yang, Y. Determinants of consumers' choices in hotel online searches: A comparison of consideration and booking stages. Int. J. Hosp. Manag. 2020, 86, 102370. [CrossRef]

15. Dolasinski, M.J.; Roberts, C.; Zheng, T. Measuring Hotel Channel Mix: A DEA-BSC Model. J. Hosp. Tour. Res. 2019, 43, 188-209. [CrossRef]

16. Toh, R.S.; Dekay, C.F.; Raven, P. Travel planning: Searching for and booking hotels on the internet. Cornell Hosp. Q. 2011, 52, 388-398. [CrossRef]

17. Kadam, V.V.; Janvekar, D. An Analysis of the effects of OTAS on travel agents in Hotel Room Bookings. IJEMER 2020, 9, 20-29.

18. Kim, J.; Franklin, D.; Phillips, M.; Hwang, E. Online Travel Agency Price Presentation: Examining the Influence of Price Dispersion on Travelers' Hotel Preference. J. Travel. Res. 2020, 59, 704-721. [CrossRef]

19. Kim, S.Y.; Kim, J.U.; Park, S.C. The Effects of Perceived Value, Website Trust and Hotel Trust on Online Hotel Booking Intention. Sustainability 2017, 8, 1. [CrossRef]

20. Ivanov, I.; Athanasova, I. Hotel Reservations via online travel agency Booking.com. EU Dimentions of the "Best Price" Clause. In Proceedings of the International Conference on Innovations in Science and Education, Prague, Czech Repuclic, 20-22 March 2019.

21. Rianthong, N.; Dumrongsiri, A.; Kohda, Y. Improving the multidimensional sequencing of hotel rooms on an online travel agency web site. Electron. Commer. R. A 2016, 17, 74-86. [CrossRef]

22. Raguseo, E.; Neirotti, P.; Paolucci, E. How small hotels can drive value their way in infomediation. The case of 'Italian hotels vs. OTAs and TripAdvisor'. Inform. Manag. 2017, 54, 745-756. [CrossRef]

23. Singh, S.; Srivastava, P. Social media for outbound leisure travel: A framework based on technology acceptance model (TAM). J. Tour. Futures 2019, 5, 43-61. [CrossRef]

24. Chatzigeorgiou, C.; Christou, E. Social media in tourism marketing: Travellers' attitudes and encounters. In Proceedings of the TOURMAN 2019 Conference Proceedings, Thessaloniki, Greece, 24-27 October 2019; Christou, E., Alexandris, K., Fotiadis, A., Eds.; International Hellenic University: Thessaloniki, Greece, 2019; pp. 164-173. 
25. Chatzigeorgiou, C.; Christou, E. Adoption of social media as distribution channels in tourism marketing: A qualitative analysis of consumers' experiences. JTHSM 2020, 6, 25-32.

26. Noor, M.N.M.; Sreenivasan, J.; Ismail, H. Malaysian Consumer Attitudes towards Mobile Advertising, the Role of Permission and Its Impact on Purchase Intention: A Structural Equation Modeling Approach. Asian Soc. Sci. 2013, 9, 135-153. [CrossRef]

27. Jayawardhena, C.; Kuckertz, A.; Karjaluoto, H.; Kautonen, T. Antecedents to permission based mobile marketing: An initial examination. Eur. J. Mark. 2009, 43, 473-499. [CrossRef]

28. Karjaluoto, H.; Lehto, H.; Leppaniemi, M.; Jayawardhena, C. Exploring gender influence on customer's intention to engage permission-based mobile marketing. Electron. Mark. 2008, 18, 242-259. [CrossRef]

29. Theocharidis, A.I.; Karavasilis, G.; Vrana, V.; Kehris, E.; Antoniadis, K. What Is Affecting Customers' Intention to Perform Social Media Marketing Activities In The Hotel Industry? In Exploring SmartTourism: The Cultural and Sustainability Synergies; Katsoni, V., Ed.; Springer: Cham, Switzerland, 2019; pp. 375-391.

30. Davis, F.; Bagozzi, R.; Warshaw, P. User Acceptance of Computer Technology: A Comparison of Two Theoretical Models. Manag. Sci. 1989, 35, 82-1003. [CrossRef]

31. Ursavas, O.M. Reconsidering the role of attitude in the TAM: An answer to Teo (2009) and Nistor and Heymann (2010), and Lopez-Bonilla and Lopez-Bonilla (2011). BJET 2013, 4, E22-E25. [CrossRef]

32. Karavasilis, I.; Vrana, V.; Zafiropoulos, K. An Extended Model of E-Government Adoption by Civil Servants in Greece. IJEGR 2016, 12, 1-23. [CrossRef]

33. Davis, F. Perceived Usefulness, Perceived Ease of Use, and User Acceptance of Information Technology. MIS Q. 1980, 13, 318-341. [CrossRef]

34. Davis, F.; Venkatesh, V. A critical assessment of potential measurement biases in the technology acceptance model: Three experiments. Int. J. Hum.-Comp. Stud. 1996, 45, 19-45. [CrossRef]

35. Venkatesh, V.; Davis, F. A Theoretical Extension of the Technology Acceptance Model: Four Longitudinal Field Studies. Manag. Sci. 2000, 46, 186-204. [CrossRef]

36. Venkatesh, V.; Bala, H. Technology Acceptance Model 3 and a Research Agenda on Interventions. Decis. Sci. 2008, 39, 273-315. [CrossRef]

37. Venkatesh, V.; Morris, M.; Davis, G.B.; Davis, F.D. User Acceptance of Information Technology: Toward a Unified View. MIS Q. 2003, 27, 425-478. [CrossRef]

38. Roberts, S.C.; Ghazizadeh, M.; Lee, J.D. Warn me now or inform me later: Drivers' acceptance of real-time and post-drive distraction mitigation systems. Int. J. Hum. Comp. Stud. 2012, 70, 967-979. [CrossRef]

39. Lai, P.C.; Zainal, A.A. Consumers' Intention to Use a Single Platform E-Payment System: A Study among Malaysian Internet and Mobile Banking Users. JIBC 2015, 20, 1-13.

40. Wu, J.H.; Wang, S.C.; Lin, L.M. Mobile computing acceptance factors in the healthcare industry: A structural equation model. Int. J. Med. Inform. 2007, 76, 66-77. [CrossRef] [PubMed]

41. Shin, D.-H.; Kim, W.-Y. Applying the Technology Acceptance Model and Flow Theory to Cyworld User Behavior: Implication of the Web2.0 User Acceptance. Cyber. Psychol. Behav. 2008, 11, 378-382. [CrossRef]

42. Lee, S.; Cho, M. Social media use in a mobile broadband environment: Examination of determinants of twitter and facebook use. IJMM 2011, 6, 71-87.

43. Sledgianowski, D.; Kulviwat, S. Using Social Network Sites: The Effects of playfulness, critical mass and trust in a hedonic context. J. Comput. Inform. Syst. 2009, 49, 74-83.

44. El-Haddadeh, R.; Weerakkody, V.; Peng, J. Social networking services adoption in corporate communication: The case of China. J. Enterp. Inf. Manag. 2012, 25, 559-575. [CrossRef]

45. Mahan, J. Examining the predictors of consumer response to sport marketing via digital social media. Int. J. Sport Manag. Mark. 2011, 9, 254-267.

46. Dodds, W.B.; Monroe, K.B.; Grewal, D. Effects of price, brand, and store information on buyers' product evaluations. J. Mark. Res. 1991, 28, 307-319.

47. Lien, C.H.; Wen, M.J.; Huang, L.C.; Wu, K.L. Online hotel booking: The effects of brand image, price, trust and value on purchase intentions. Asia Pac. Manag. Rev. 2015, 20, 210-218. [CrossRef]

48. Hajli, M.N. A study of the impact of social media to consumers. Int. J. Market. Res. 2014, 56, 387-404. [CrossRef]

49. Grabner-Kräuter, S. Building Consumer Trust in Online Markets. In Business Ethics and Electronic Economy; Koslowski, P., Fisher, P., Eds.; Springer: Berlin/Heidelberg, Germany, 2004. 
50. Gefen, D.; Straub, D.W. Consumer Trust in B2C e-Commerce and the importance of social presence: Experiments in e-Products and e-Services. Omega 2004, 32, 407-424. [CrossRef]

51. Thaw, Y.Y.; Mahmood, A.K.; Dominic, P. A Study on the Factors That Influence the Consumers Trust on Ecommerce Adoption. IJCSNS 2009, 4.

52. Cheung, C.M.K.; Lee, M.K.O. Understanding Consumer Trust in Internet Shopping: A Multidisciplinary Approach. J. Am. Soc. Inf. Sci. Technol. 2006, 57, 479-492. [CrossRef]

53. Grabner-Kräuter, S.; Kaluscha, A.E. Consumer trust in electronic commerce: Conceptualization and classification of trust building measures. In Trust and New Technologies: Marketing and Management on the Internet and Mobile Media; Kautonen, T., Karjaluoto, H., Eds.; Edward Elgar: Cheltenham, UK, 2008; pp. 3-22.

54. Xu, G.; Feng, Z.; Wu, H.; Zhao, D. Swift trust in virtual temporary system: A model based on the Dempster-Shafer theory of belief functions. Int. J. Electron. Commer. 2007, 12, 93-126. [CrossRef]

55. McKnight, H.; Chervany, N. What Trust Means in E-Commerce Customer Relationships: An Interdisciplinary Conceptual Typology. Int. J. Electron. Commer. 2002, 6, 35-59. [CrossRef]

56. McKnight, N.; Choudhury, V.; Kacmar, C. Developing and Validating Trust Measures for e-Commerce: An Integrative Typology. Inf. Syst. Res. 2002, 13, 334-359. [CrossRef]

57. Pennanen, K.; Kaapu, T.; Paakki, M.K. Trust, Risk, Privacy, and Security in e-Commerce. In Frontiers of e-Business Research; Tampere University of Technology (TUT) and University of Tampere (UTA): Tampere, Finland, 2006.

58. Mayer, R.; Davis, J.; Schoorman, D. An integrative model of organizational trust. Acad. Manag. Rev. 1995, 20, 709-734. [CrossRef]

59. Walterbusch, M.; Gräuler, M.; Teuteberg, F. How Trust is Defined: A Qualitative and Quantitative Analysis of Scientific Literature. In Proceedings of the 20th Americas Conference on Information Systems, AMCIS 2014, Savannah, GA, USA, 7-10 August 2014.

60. Whitener, E.M.; Brodt, S.E.; Korsgaard, M.A.; Werner, J.M. Managers as Initiators of Trust: An Exchange Relationship Framework for Understanding Managerial Trustworthy Behavior. Acad. Manag. Rev. 1998, 23, 513-530. [CrossRef]

61. Kim, Y.; Ahmad, M. Trust, distrust and lack of confidence of users in online social media-sharing communities. Knowl. Based Syst. 2013, 37, 438-450. [CrossRef]

62. Barnes, S.; Scornavacca, E. Mobile marketing: The role of permission and acceptance. Int. J. Mob. Commun. 2004, 2, 128-139. [CrossRef]

63. Godin, S. Permission Marketing: Turning Strangers into Friends and Friends into Customers; Simon \& Schuster: London, UK, 1999.

64. Im, H.; Ha, Y. Enablers and inhibitors of permission-based marketing: A case of mobile coupons. J. Retail. Consum. Serv. 2013, 20, 495-503. [CrossRef]

65. Karimi, S.; Stoev, Y.G.; Zander, O. Ethical Issues in E-Permission Marketing. Master's Thesis, Jönköping University, Jönköping, Sweden, 2017.

66. Krafft, M.; Arden, C.; Verhoef, P. Permission Marketing and Privacy Concerns-Why Do Customers (Not) Grant Permissions? J. Interact. Mark. 2017, 39, 39-54. [CrossRef]

67. Gao, T.; Rohm, A.; Sultan, F.; Pagani, M. Consumers un-tethered: A three-market empirical study of consumers' mobile marketing acceptance. J. Bus. Res. 2013, 66, 2536-2544. [CrossRef]

68. Castronovo, C.; Huang, L. Social Media in an Alternative Marketing Communication Model. JMDC 2012, 31, 117-134.

69. Karjaluoto, H.; Jayawardhena, C.; Kuckertz, A.; Kautonen, T. Sources of trust in permission based mobile marketing: A cross-country comparison. In Trust and New Technologies, Marketing and Management on Internet and Mobile Media; Kautonen, T., Karjaluoto, H., Eds.; Edward Elgar: Northampton, MA, USA, 2008.

70. Gordon, G.L.; Schoenbachler, D.D. Trust and customer willingness to provide information in database-driven relationship marketing. J. Interact. Mark. 2002, 16, 2-16.

71. Shen, Z.; Siau, K. Building customer trust in mobile commerce. Commun. ACM 2003, 46, 91-94.

72. Appel, G.; Grewal, L.; Hadi, R.; Stepthen, A. The future of social media in marketing. J. Acad. Mark. Sci. 2020, 48, 79-95. [CrossRef] [PubMed] 
73. Schweigert, V.A.; Geyer-Schulz, A. The Impact of the General Data Protection Regulation on the Design and Measurement of Marketing Activities: Introducing Permission Marketing and Tracking for Improved Marketing \& CRM Compliance with Legal Requirements. JMDC 2019, 13, 13.

74. Wearsocial 2020. Digital 2020. Available online: https://wearesocial.com/blog/2020/07/more-than-half-of-thepeople-on-earth-now-use-social-media (accessed on 29 September 2020).

75. Hootsuite 2020. Digital 2020. July Global Stathot Report. Available online: https://hootsuite.widen.net/s/ ugpuk74q5j (accessed on 29 September 2020).

76. Metev, D. How Much Time Do People Spend on Social Media? [63+ Facts to Like, Share and Comment]. 2020. Available online: https://review42.com/how-much-time-do-people-spend-on-social-media/\#: \{\}:text=The \% 20average\%20US\%20adult\%20spends, was\%20142\%20minutes\%20a\%20day (accessed on 29 September 2020).

77. Lee, D.; Hosanagar, K.; Nair, H. Advertising Content and Consumer Engagement on Social Media: Evidence from Facebook. Manag. Sci. 2018, 64, 5105-5131. [CrossRef]

78. Aaker, D.A.; Jacobson, R. The Value Relevance of Brand Attitude in High-Technology Markets. J. Mark. Res. 2001, 38, 485-493. [CrossRef]

79. Chadwick, M.B. Engaging Consumers via Social Media Makes Them More Likely to Buy, Recommend. 2010. Available online: https:/www.greenbook.org/marketing-research/engaging-consumers-via-social-media (accessed on 11 May 2020).

80. Abzari, M.; Ghassemi, R.A.; Vosta, L.N. Analysing the effect of social media on brand attitude and purchase intention: The case of Iran Khodro company. Procedia Soc. Behav. Sci. 2014, 143, 822-826. [CrossRef]

81. Blomfield-Neira, C.; Barber, B. Social networking site use: Linked to adolescents' social self-concept, self-esteem, and depressed mood. Aust. J. Psychol. 2014, 66, 56-64. [CrossRef]

82. Hu, T.; Zhang, P. Social Media Usage as a formative construct: Conceptualization, Validation and implication. J. Inf. Technol. Manag. 2016, XXVVV, 155-168.

83. Hussain, S.A.E.; Illiasu, A. Purchasing intention, family values and social media usage affecting online purchasing habits among youths. AJAC 2019, 2682, 7506.

84. Park, D.-H.; Lee, J.; Han, I. The Effect of On-Line Consumer Reviews on Consumer Purchasing Intention: The Moderating Role of Involvement. Int. J. Electron. Commer. 2007, 11, 125-148. [CrossRef]

85. Coursaris, C.; Osch, W.; Balogh, B. Do Facebook Likes Lead to Shares or Sales? Exploring the Empirical Links between Social Media Content, Brand Equity, Purchase Intention, and Engagement. In Proceedings of the 49th Hawaii International Conference on System Sciences (HICSS), Koloa, HI, USA, 5-8 January 2016; pp. 3546-3555.

86. Pucci, T.; Casprini, E.; Nosi, C.; Zanni, L. Does social media usage affect online purchasing intention for wine? The moderating role of subjective and objective knowledge. Br. Food J. 2019, 121, 275-288. [CrossRef]

87. Kamal, S.; Chu, S.C.; Pedram, M. Materialism, Attitudes, and Social Media Usage and Their Impact on Purchase Intention of Luxury Fashion Goods among American and Arab Young Generations. JIA 2013, 13, 27-40. [CrossRef]

88. Julious, S. Sample size of 12 per group rule of thumb for a pilot study. Pharm. Stat. 2005, 4, $287-291$. [CrossRef]

89. Dimitriadis, S.; Vrana, V.; Dimitriou, S.; Kalaitzis, V.; Drogalas, G. Investigating customer satisfaction and service quality in academic libraries: The case of Technological Educational Institute of Central Macedonia. IJSDS 2013, 5, 48-66. [CrossRef]

90. Hancock, G.R.; Mueller, R.O. (Eds.) Structural Equation Modeling: A Second Course, 2nd ed.; IAP, Information Age Publishing: Washington, DC, USA, 2013.

91. Rosseel, Y. lavaan: An R Package for Structural Equation Modeling. J. Stat. Softw. 2012, 48, 1-36. [CrossRef]

92. Finch, W.H.; French, B.F. Latent Variable Modeling with R; Routledge: New York, NY, USA, 2015.

93. Fornell, C.; Larcker, D.F. Evaluating structural equation models with unbearable and measurement error. J. Mark. Res. 1981, 18, 39-50. [CrossRef]

94. Akar, E.; Topçu, B. An Examination of the Factors Influencing Consumers' Attitudes Toward Social Media Marketing. J. Internet Commer. 2011, 10, 35-67. [CrossRef]

95. O'Cass, A.; Carlson, J. An e-retailing assessment of perceived website-service innovativeness: Implications for website quality evaluations, trust. AMJ 2012, 20, 28-36.

96. Teo, T.; Srivastava, S.; Jiang, L. Trust and Electronic Government Success: An Empirical Study. J. Manag. Inf. Syst. 2008, 25, 99-131. [CrossRef] 
97. Hair, F., Jr.; Anderson, R.E.; Tatham, R.L.; Black, W.C. Multivariate Data Analysis, 5th ed.; Prentice Hall: Upper Saddle River, NJ, USA, 1998.

98. Gold, A.H.; Malhotra, A.; Segars, A.H. Knowledge management: An organization capabilities perspective. JMIS 2001, 18, 185-214. [CrossRef]

99. Bagozzi, R.; Yi, Y. On the Evaluation of Structural Equation Models. J. Acad. Mark. Sci. 1988, 16, 74-94. [CrossRef]

100. Hansen, J.M.; Saridakis, G.; Benson, V. Risk, trust, and the interaction of perceived ease of use and behavioral control in predicting consumers' use of social media for transactions. Comput. Hum. Behav. 2018, 80, 197-206. [CrossRef]

101. Sin, S.S.; Nor, K.M.; Al-Agaga, M.A. Factors Affecting Malaysian young consumers' online purchase intention in social media websites. Procedia Soc. Behav. Sci. 2012, 40, 326-333. [CrossRef]

102. Yahia, I.B.; Al-Neama, N.; Kerbache, L. Investigating the drivers for social commerce in social media platforms: Importance of trust, social support and the platform perceived usage. J. Retail. Consum. Serv. 2018, 41, 11-19. [CrossRef]

103. Kanchanatanee, K.; Suwanno, N.; Jarernvongrayab, A. Effects of Attitude toward Using, Perceived Usefulness, Perceived Ease of Use and Perceived Compatibility on Intention to Use E-Marketing. J. Manag. Res. 2014, 6, 1-13. [CrossRef]

104. Mariani, M.; Ek Styven, M.; Ayeh, J.K. Using Facebook for travel decision-making: An international study of antecedents. Int. J. Contemp. Hosp. Manag. 2019, 31, 1021-1044. [CrossRef]

105. Saprikis, V.; Markos, A.; Zarmpou, T.; Vlachopoulou, M. Mobile Shopping Consumers' Behavior: An Exploratory Study and Review. J. Theor. Appl. Electron. Commer. Res. 2018, 13, 71-90. [CrossRef]

106. Lee, J.H.; Lee, C.F. Extension of TAM by Perceived Interactivity to Understand Usage Behaviors on ACG Social Media Sites. Sustainability 2019, 11, 5723. [CrossRef]

107. Lee, Y.; Kozar, K.A.; Larsen, K.R.T. The technology acceptance model; past, present and future. Commun. AIS 2003, 12, 752-780. [CrossRef]

108. Cha, J. Shopping on social networking websites: Attitudes toward real versus virtual items. J. Interact. Advert. 2009, 10, 77-93. [CrossRef]

109. Salem, M.S.; Althuwaini, S.; Habib, S. Mobile advertising and its impact on message acceptance and purchase Intention. JBRMR 2018, 12, 92-103. [CrossRef]

110. Kautonen, T.; Karjaluoto, H.; Jayawardhena, C.; Kuckertz, A. Permission-based mobile marketing and sources of trust in selected European markets. JESIT 2007, 9, 104-123. [CrossRef]

111. Agag, G.; El-Masry, A. Why Do Consumers Trust Online Travel Websites? Drivers and Outcomes of Consumer Trust toward Online Travel Websites. J. Travel Res. 2017, 56, 347-369. [CrossRef]

112. Tucker, C.E. Social networks, personalized advertising and privacy controls. J. Mark. Res. 2014, 51, 546-562. [CrossRef]

113. Weerasinghe, S.; Chandanie, M.; Hindagolla, B. Technology acceptance model and social network sites (SNS): A selected review of literature. Glob. Knowl. Mem. Commun. 2018, 67, 142-153. [CrossRef]

114. Liang, T.P.; Chen, C.Y.; Du, T.; Turban, E.; Li, Y. Effect of personalization on the perceived usefulness of online customer services: A dual-core theory. J. Electron. Commer. Res. 2012, 13, 275-288.

115. Duncan, T.; Moriarty, S. A Communication-Based Marketing Model for Managing Relationships. J. Mark. 1998, 62, 1-13. [CrossRef]

116. Muresan, I.C.; Oroian, C.F.; Harun, R.; Arion, F.H.; Porutiu, A.; Chiciudean, G.O.; Todea, A.; Lile, R. Local Residents' Attitude toward Sustainable Rural Tourism Development. Sustainability 2016, 8, 100. [CrossRef]

117. Sheivachman, A. The Greening of Travel. SKI Mag. 2020, 14, 6-22.

118. Calcagni, F.; Amorim Maia, A.T.; Connolly, J.J.T.; Langemeyer, J. Digital co-construction of relational values: Understanding the role of social media for sustainability. Sustain. Sci. 2019, 14, 1309-1321. [CrossRef]

119. Diez-Martin, F.; Blanco-Gonzalez, A.; Prado-Roman, C. Research Challenges in Digital Marketing: Sustainability. Sustainability 2019, 11, 2839. [CrossRef]

120. Sigala, M. Tourism and COVID-19: Impacts and implications for advancing and resetting industry and research. J. Bus. Res. 2020, 117, 312-332. [CrossRef] [PubMed]

121. UNWTO World Tourism Barometer and Statistical Annex, May 2020 UNWTO World Tourism Barometer (English Version). 2020. Available online: https://www.e-unwto.org/doi/abs/10.18111/wtobarometereng.2020. 18.1.2 (accessed on 30 September 2020). 
122. Jiang, Y.; Wen, J. Effects of COVID-19 on hotel marketing and management: A perspective article. Int. J. Contemp. Hosp. Manag. 2020, 32, 2563-2573. [CrossRef]

123. Data Report. Digital 2020: Greece. 2020. Available online: https://datareportal.com/reports/digital-2020greece (accessed on 30 September 2020).

124. IOBE. Greece 2020: Factsheet on Digital Transformation. 2020. Available online: http://iobe.gr/ EC_Conference2020/Factsheet_Digital\%20Transformation_Greece\%20July\%202020.pdf (accessed on 30 September 2020).

Publisher's Note: MDPI stays neutral with regard to jurisdictional claims in published maps and institutional affiliations.

(C) 2020 by the authors. Licensee MDPI, Basel, Switzerland. This article is an open access article distributed under the terms and conditions of the Creative Commons Attribution (CC BY) license (http://creativecommons.org/licenses/by/4.0/). 